\title{
PERSEPSI ORANG TUA SISWA SMP TENTANG PEMBELAJARAN DARING MATA PELAJARAN MATEMATIKA
}

\author{
Oleh : \\ Tiarmada Nestoria Tumanggor'), Zulfadli Nasution'), Muhammad Syahril Harahap ${ }^{\text {3) }}$
Institut Pendidikan Tapanuli Selatan
}

\begin{abstract}
ABSTRAK
Penelitian ini bertujuan untuk mengetahui bagaimana gambaran persepsi orang tua siswa kelas VIII-C SMP Negeri 2 Manduamas tentang pembelajaran daring. Penelitian ini dilaksanakan di kecamatan Manduamas. Metode penelitian yang digunakan metode kuantitatif deskriptif. Populasi penelitian ini adalah seluruh orang tua siswa di kelas VIII-C SMP Negeri 2 Manduamas yang berjumlah 30 orang. Sampel dalam penelitian ini berjumlah 30 orang. Teknik pengumpulan data yang digunakan adalah teknik angket. Teknik analisis data adalah deskriptif. Hasil penelitian yang dilakukan diketahui nilai mean sebesar 3.16 dan nilai median sebesar 3.38, nilai modus adalah sebesar 3.28. Gambaran persepsi orangtua siswa kelas VIII-C pada aspek perhatian diperoleh nilai rata-rata sebesar 3.13 yakni berada pada katagori sangat baik. Gambaran persepsi orangtua siswa kelas VIII-C pada aspek tanggapan (respon) diperoleh nilai rata-rata 3.20 yakni berada pada katagori sangat baik. Gambaran persepsi orangtua siswa kelas VIII-C pada aspek Penilaian diperoleh nilai rata-rata 3.14 berada pada katagori sangat baik.
\end{abstract}

\section{Kata Kunci: Persepsi, Orang Tua, Pembelajaran Daring.}

\section{PENDAHULUAN}

Pembelajaran yang awalnya terlaksana secara tatap muka di sekolah namun sejak virus COVID-19 di Indonesia saat ini berdampak bagi seluruh masyarakat termasuk pelaksanaan pembelajaran. Dampak dari penyebaran virus COVID-19 di Indonesia menyebabkan pembelajaran yang dilaksanakan secara tatap muka akhirnya dilaksanakan secara daring. Pelaksanaan pembelajaran daring menjadi salah satu alternatif agar pendidikan terus berjalan di tengah pembatasan sosial yang dianjurkan oleh pemerintah.

Kondisi ini malah membuat pelaksanaan pembelajaran secara daring menyebabkan berbagai permasalahan mulai dari segi guru dalam pelaksanaan pembelajarannya sampai dengan permasalahan bagaimana proses pelaksanaannya (Simanjuntak et al., 2020). Hal ini sesuai dengan hasil wawancara yang dilakukan dengan salah satu guru di SMP Negeri 2 Manduamas permasalahan dalam pembelajaran daring khususnya dalam pembelajaran matematika seperti guru masih terkendala dalam menggunakan berbagai aplikasi pembelajaran secara daring, guru kesulitan melakukan penilaian terhadap pembelajaran yang dilakukan terutama penilaian sikap dan keterampilan. Berdasarkan hasil wawancara peneliti dengan salah satu orang tua siswa VIII-C SMP Negeri 2 Manduamas yang tinggal di desa Binjohara Uruk Kecamatan Manduamas menyatakan bahwa sangat kewalahan dengan sistem belajar daring. Karena masih banyak orang tua atau siswa yang tidak memiliki handpone atau adroid yang bisa mengakses internet. Di samping itu, kurangnya biaya untuk mengisi paket atau pulsa. Sehingga banyak anak yang tidak bisa belajar secara daring.

Pada dasarnya ada beberapa faktor yang mempengaruhi pesersip orang tua siswa terhadap pelaksanaan pembelajaran daring khususnya pada mata pelajaran matematika. Beberapa faktor tersebut dapat dikelompokkan menjadi faktor yang bersumber dari dalam diri dan faktor yang bersumber dari luar. Persepsi orang tua terkait pelaksanaan pembelajaran daring pada mata pelajaran matematika dipengaruhi faktor kebutuhan dimana para orang tua harus memenuhi semua fasilitas dan kebutuhan anaknya dalam melaksanakan pembelajaran secara daring. Kemudian para orang tua khawatir anak-ananya tidak bisa secara tuntas dalam mempelajari pembelajaran matematika. Perasaan orang tua pelajaran matematika yang sulit disampaikan secara online akan sulit dipahami oleh anak-anaknya sehingga nantinya ke jenjang berikutnya para siswa kesulitan untuk menyesuaikan dalam pembelajaran matematika. 
Manduamas merupakan salah satu kecamatan yang mengharuskan warganya untuk belajar di rumah. Pembelajaran yang biasanya dilakukan secara klasikal atau berlangsung di kelas, sekarang harus dilakukan secara daring atau online. Pergeseran cara belajar dari klasikal ke online menimbulkan beberapa hambatan. Hambatan utama yang dirasakan jaringan internet yang tidak merata kekuatannya. Khususnya kecamatan Manduamas desa Binjohara Uruk belum memiliki akses internet yang bagus. Masyarakat Manduamas juga masih banyak yang memiliki ekonomi lemah atau kurang mampu. Berdasarkan uraian di atas, maka peneliti menganalisis persepsi Orang Tua Siswa Kelas VIII-C SMP Negeri 2 Manduamas tentang Pembelajaran Daring Mata Pelajaran Matematika di Kecamatan Manduamas.

\section{Hakikat Persepsi Orang Tua Siswa}

Persepsi pada hakikatnya merupakan proses dimana individu dapat mengenal objek dan fakta dengan menggunakan alat indera. Menurut Slameto (2010:102), "Persepsi adalah proses yang menyangkut masuknya pesan atau informasi ke dalam otak manusia. Melalui persepsi, manusia terusmenerus mengadakan hubungan dengan lingkungannya. Hubungan itu dilakukan lewat inderanya, yaitu indera penglihat, pendengar, peraba, perasa dan pencium." Orang tua adalah orang yang bertanggung jawab dalam satu keluarga atau rumah tangga yang biasa disebut ibu atau bapak. Orang tua juga merupakan ibu dan ayah dan masing-masing mempunyai tanggung jawab yang sama dalam Pendidikan anak. Menurut Safitri (2015:60), "Orang tua adalah guru pertama dan yang terutama didalam keluarga"

Persepsi seseorang dapat dilihat dari beberapa aspek seperti perhatiannya terhadap objek yang dipersepsikan kemudian pendapatnya terhadap objek tersebut. Menurut Slameto (2010:105) "Perhatian adalah kegiatan yang dilakukan oleh seseorang dalam hubungannya dengan pemilihan ransangan yang datang dari lingkungannya. Tanggapan dapat disebut dengan kesan yang diperlihatkan oleh seseorang setelah mengatami suatu objek. Tanggapan dapat berupa negatif atau juga positif. Menurut Yamanda (2018:86) "Tanggapan sebagai salah satu fungsi jiwa dapat diartikan sebagai gambaran atau bayangan yang tertinggal dalam diri manusia sesudah melakukan persepsi terhadap suatu obyek atau peristiwa." Persepsi juga melahirkan penilaian selain tanggapan seseorang mengamati atau menanggapi suatu objek akan memberikan penilaian. Yamanda (2018:86) menyatakan bahwa "Rangsang-rangsang dari luar yang telah ditangkap indera, kemudian dievaluasi oleh individu. Evaluasi ini sangat subjektif. Individu yang satu menilai suatu rangsang sebagai sesuatu yang sulit dan membosankan. Tetapi individu yang lain menilai rangsang yang sama tersebut sebagai sesuatu yang bagus dan menyenangkan."

\section{Hakikat Pembelajaran Daring Pada Mata Pelajaran Matematika}

Pemanfaatan teknologi telekomunikasi untuk kegiatan pembelajaran di sekolah semakin kondusif dengan munculnya sistem pembelajaran daring. Menurut Permana (2016:153), "Istilah daring merupakan akronim dari dalam jaringan. Jadi pembelajaran daring adalah salah satu metode pembelajaran online atau dilakukan melalui jaringan internet”. Menurut Adhisuwignjo (2020:4-6) menyatakan bahwa "Pelaksanaan Pembelajaran daring melalui 3 tahapan yaitu persiapan, pelaksanaan dan penilaian.

Berdasarkan uraian diatas dapat disimpulkan bahwa pembelajaran daring merupakan cara berkomunikasi dimana penyampaiannya dan penerima pesan-pesan dilaksanakan melalui jaringan internet. Pembelajaran daring yang akan dikaji adalah pembelajaran pada mata pelajaran matematika. Matematika merupakan salah satu mata pelajaran wajib di berbagai sekolah mulai dari jenjang sekolah dasar sampai sekolah tinggi.

\section{METODOLOGI}

Penelitian ini dilaksanakan di kecamatan Manduamas, kabupaten Tapanuli Tengah provinsi Sumatera Utara. Metode penelitian yang digunakan dalam penelitian ini adalah metode kuantitatif deskriptif. Priyatno (2011:8) menyatakan bahwa, "analisis deskriptif adalah analisis yang menekankan pada pembahasan data-data dan subjek penelitian dengan menyajikan data-data secara sistematik dan tidak menyimpulkan hasil penelitian".

\section{Populasi dan Sampel}

Margono (2010:118) "populasi adalah seluruh data yang menjadi perhatian kita dalam suatu ruang lingkup dan waktu yang kita tentukan. populasi diukur adalah populasi yang secara rill 
dijadikan dasar dalam penentuan sampel, dan secara langsung menjadi lingkungan sasaran keberlakuan kesimpulan."

Berdasarkan pendapat diatas dapat disimpulkan bahwa populasi adalah sejumlah subjek yang dijadikan objek penelitian yang ditetapkan oleh peneliti untuk diketahui dan kemudian ditarik kesimpulan. Adapun populasi penelitian ini adalah seluruh orang tua siswa di kelas VIII-C SMP Negeri 2 Manduamas yang berjumlah 30 orang. Mengingat populasi relatif kecil dan homogen, maka peneliti menetapkan teknik pengambilan sampel dalam penelitian ini menggunakan teknik Total Sampling, sehingga jumlah sampel dalam penelitian ini adalah seluruh orang tua siswa kelas VIII-C yang berjumlah 30 orang.

\section{Intrumen Penelitian}

Instrumen penelitian adalah pedoman tertulis tentang wawancara, atau pengamatan, atau daftar pertanyaan, yang dipersiapkan untuk mendapatkan informasi. Instrumen itu disebut pedoman pengamatan atau pedoman wawancara atau kuesioner atau pedoman dokumenter ,sesuai dengan metode yang dipergunakan. Djaali dan muljono (2008:59) menyatakan bahwa "Instrumen atau alat pengumpul data adalah alat yang digunakan untuk mengumpulkan data dalam suatu penelitian." Penyusunan instrumen dilakukan berdasarkan kepada kedua variabel penelitian. Adapun instrumen yang digunakan dalam penelitian ini ialah sebagai berikut :

\section{Tabel 1}

Indikator Persepsi Orang Tua Siswa Tentang Pembelajaran Daring

\begin{tabular}{lllc}
\hline No & \multicolumn{1}{c}{ Indikator } & \multicolumn{1}{c}{ Nomor Soal } & Jumlah Pernyataan \\
\hline 1 & Perhatian (Attention) & $1,2,3,4,5,6,7$ & 7 \\
\hline 2 & Tanggapan (Respon) & $8,9,10,11,12,13,14$ & 7 \\
\hline 3 & Penilaian & $15,16,117,18,19,20$ & 6 \\
\hline Jumlah & & 20 \\
\hline
\end{tabular}

Sesuai dengan kisi-kisi instrumen di atas tiap indikator dibuat ke dalam bentuk angket dengan jumlah 20 butir pernyataan. Adapun skala yang akan digunakan dalam lembar instrumen angket tersebut adalah skala likert. Sugiyono (2011:134) menyatakan bahwa, "Skala likert digunakan untuk mengukur sikap, pendapat dan persepsi seseorang atau sekelompok orang tentang fenomena sosial". Maka dalam hal ini peneliti menyimpulkan instrumen yang digunakan untuk mendapatkan data tentang persepsi orangtua terhadap pembelajaran daring pada mata pelajaran matematika. Adapun option yang digunakan adalah sangat setuju (SS) diberi skor 4, setuju (S) diberi skor 3, ragu-ragu (RR) diberi skor 2, tidak setuju (TS) diberi skor 1.

\section{Teknik Pengumpulan Data}

Tekik pengumpulan data diperlukan oleh peneliti untuk mengumpulkan data dalam proses penelitian, teknik pengumpulan data yang digunakan peneliti ialah angket. Angket merupakan teknik pengumpulan data yang dilakukan dengan cara memberi seperangkat pertanyaan atau pernyataan secara tertulis kepada responden untuk dijawabnya. Umar (2009: 49) menyatakan bahwa, "Teknik angket merupakan suatu pengumpulan data dengan memberi atau menyebarkan daftar pertanyaan/pernyataan kepada responden dengan harapan memberikan respon atas daftar pertanyaan tersebut". Sugiyono (2010:142) menyatakan bahwa, "Kuesioner merupakan teknik pengumpulan data yang dilakukan dengan cara memberi seperangkat pertanyaan atau pernyataan tertulis kepada responden untuk dijawabnya”. Angket digunakan untuk mendapatkan data tentang pembelajaran berbasis masalah. Adapun jumlah pernyataan yang dibuat dalam angket sebanyak 20 butir pernyataan.

\section{Teknik Analisis Data}

Teknik analisis data pada penelitian ini menggunakan analisis statistik deskriptif. Analisis deskriptif dimaksudkan untuk mendeskripsikan sub variabel penelitian sehingga diketahui sebaran datanya. Analisis yang dipakai adalah menghitung nilai rata-rata/mean (M), median (Me), modus (Mo), dan standar deviasi (SDi), tabel distribusi frekuensi, penyajian histogram, tabel kecenderungan masing-masing sub variabel dan grafik distribusi frekuensi kecenderungan variabel.
a. Perhitungan mean:
b. Perhitungan Median:
c. Perhitungan standar deviasi (SDi) 
d. Membuat Tabel Distribusi Frekuensi

1) Menghitung rentang data/jangkauan ( $R)$ dengan rumus:

Rentang data $=$ data terbesar - data terkecil

2) Menentukan jumlah kelas interval dengan menggunakan rumus Sturges, yaitu:

$\mathrm{K}=1+3,3 \log \mathrm{n}$

3) Menghitung panjang kelas.

Panjang kelas $=$ rentang data $(\mathrm{R}):$ jumlah kelas $(\mathrm{K})$

Adapun penilaian yang digunakan untk mengukur keterampilan guru dalam menjelaskan pelajaran ditetapkan sesuai pendapat

Tabel. 2

Kriteria Penilaian Angket Persepsi Orang Tua Siswa Kelas VIII-C SMP Negeri 2 Manduamas tentang Pembelajaran Daring Mata Pelajaran Matematika

di Kecamatan Manduamas

\begin{tabular}{lllllllllll}
\hline \multicolumn{8}{c}{ Simbol Simbol Nilai Angka dan Huruf } & \multirow{2}{*}{ Predikat } \\
\hline \multicolumn{10}{c}{ Angka } \\
\cline { 1 - 7 } 8 & - & 10 & $=$ & 80 & - & 100 & $=3,1-4$ & A & Sangat Baik \\
\hline 7 & - & 7,9 & $=$ & 70 & - & 79 & $=$ & $2,1-3$ & B & Baik \\
\hline 6 & - & 6,9 & $=$ & 60 & - & 69 & $=$ & $1,1-2$ & C & Cukup \\
\hline 5 & - & 5,9 & $=$ & 50 & - & 59 & $=$ & 1 & D & Kurang \\
\hline 0 & - & 4,9 & $=$ & 0 & - & 49 & $=$ & 0 & E & Gagal \\
\hline
\end{tabular}

\section{HASIL PENELITIAN DAN PEMBAHASAN}

\section{Hasil Penelitian}

Berdasarkan hasil angket Analisis Data Persepsi Orang Tua Siswa Kelas VIII-C SMP Negeri 2 Manduamas Tentang Pembelajaran Daring Mata Pelajaran Matematika Di Kecamatan Manduamas. yang diberikan kepada 30 orang tua siswa kelas VIII-C SMP Negeri 2 Manduamas diperoleh nilai tertinggi sebesar 4.00 dan terendah 2.35. Berdasarkan tabel di atas, diketahui nilai rata-rata atau mean yang diperoleh adalah sebesar 3.16 yakni berada pada kategori "Sangat Baik", nilai tengah sebesar 3.38 dan nilai yang sering muncul atau modus sebesar 3.28. Analisis Data Hasil Persepsi Orang Tua kelas VIII-C SMP Negeri 2 Manduamas tentang Pembelajaran Daring Mata Pelajaran Matematika di Kecamatan Manduamas per Indikator

\section{Deskripsi Hasil Angket pada indikator Perhatian (Attention)}

Salah satu indikator dari persepsi orang tua siswa kelas VIII-C SMP Negeri 2 manduamas tentang pembelajaran daring mata pelajaran matematika di kecamatan Manduamas adalah perhatian. Hasil angket yang disebarkan dapat dilihat pada tabel berikut:

Tabel 3

Distribusi Frekuensi Data Hasil Angket Persepsi Orang Tua Siswa Kelas VIII-C SMP Negeri 2 Manduamas Tentang Pembelajaran Daring Mata Pelajaran Matematika di Kecamatan Manduamas pada Indikator Perhatian

\begin{tabular}{clcc} 
No & Alternatif Jawaban & Frekuensi & P $=\boldsymbol{F} / \boldsymbol{N} \boldsymbol{x} \mathbf{1 0 0 \%}$ \\
\hline 1 & Sangat Setuju (SS) & 112 & 53.33 \\
\hline 2 & Setuju (S) & 46 & 21.90 \\
\hline 3 & Ragu-Ragu (RR) & 32 & 15.24 \\
\hline 4 & Tidak Setuju (TS) & 20 & 9.52 \\
\hline & Jumlah & $\mathbf{2 1 0}$ & $\mathbf{1 0 0}$
\end{tabular}

Berdasarkan tabel di atas dimana hasil angket yang diberikan kepada tiap orang tua siswa kelas VIII-C di SMP Negeri 2 Manduamas terkait dengan persepsi orang tua pada aspek perhatian orang tua pada anak saat pembelajaran daring pada mata pelajaran matematika dari 30 orang tua siswa dengan jumlah pertanyaan 210 pernyataan dimana para orangtua menjawab sangat setuju (SS) sebanyak 112 jawaban atau sekitar $53.33 \%$ dari total jawaban pada indikator perhatian, yang menjawab setuju (S) sebanyak 46 jawaban atau sekitar $21.90 \%$ dari total jawaban pada indikator 
perhatian. Kemudian jawaban Ragu-Ragu (RR) sebanyak 32 atau sekitar $15.24 \%$ dari total jawaban pada indikator perhatian, selanjutnya jawaban tidak setuju (TS) sebanyak 20 atau $9.52 \%$ dari total jawaban pada indikator perhatian. Dengan demikian dapat disimpulkan pada indikator perhatian diperoleh kesimpulan mayoritas menjawab sangat setuju dengan artian orang tua menaruh perhatian kepada anak saat belajar secara daring pada pembelajaran matematika.

\section{Deskripsi Hasil Angket pada indikator Tanggapan (Respon)}

Indikator berikutnya adalah tanggapan atau respon. Tanggapan atau respon dari persepsi orang tua siswa kelas VIII-C SMP Negeri 2 manduamas tentang pembelajaran daring mata pelajaran matematika di kecamatan Manduamas. Hasil angket yang disebarkan dapat dilihat pada tabel berikut:

Tabel 4

Distribusi Frekuensi Data Hasil Angket Persepsi Orang Tua Siswa Kelas VIII-C SMP Negeri 2 Manduamas Tentang Pembelajaran Daring Mata Pelajaran Matematika di Kecamatan Manduamas pada Indikator Tanggapan

\begin{tabular}{clcc}
\multicolumn{1}{l}{ No } & Alternatif Jawaban & Frekuensi & $\mathbf{P}=\boldsymbol{F} / \boldsymbol{N} \boldsymbol{x} \mathbf{1 0 0 \%}$ \\
\hline 1 & Sangat Setuju (SS) & 112 & 53.33 \\
\hline 2 & Setuju (S) & 43 & 20.48 \\
\hline 3 & Ragu-Ragu (RR) & 41 & 19.52 \\
\hline 4 & Tidak Setuju (TS) & 14 & 6.67 \\
\hline Jumlah & & $\mathbf{2 1 0}$ & $\mathbf{1 0 0}$
\end{tabular}

Berdasarkan tabel di atas dimana hasil angket yang diberikan kepada tiap orang tua siswa kelas VIII-C di SMP Negeri 2 Manduamas terkait dengan persepsi orang tua pada aspek tanggapan atau respon orang tua pada anak saat pembelajaran daring pada mata pelajaran matematika dari 30 orang tua siswa dengan jumlah pertanyaan 210 pernyataan dimana para orangtua menjawab sangat setuju (SS) sebanyak 112 jawaban atau sekitar $53.33 \%$ dari total jawaban pada indikator perhatian, yang menjawab setuju (S) sebanyak 43 jawaban atau sekitar $20.48 \%$ dari total jawaban pada indikator perhatian. Kemudian jawaban Ragu-Ragu (RR) sebanyak 41 atau sekitar 19.52\% dari total jawaban pada indikator perhatian, selanjutnya jawaban tidak setuju (TS) sebanyak 14 atau $6.67 \%$ dari total jawaban pada indikator perhatian.

3. Deskripsi Hasil Angket pada indikator Penilaian berikut:

Indikator berikutnya adalah penilaian hasil angket yang disebarkan dapat dilihat pada tabel

\section{Tabel 5}

Distribusi Frekuensi Data Hasil Angket Persepsi Orang Tua Siswa Kelas VIII-C SMP Negeri 2 Manduamas Tentang Pembelajaran Daring Mata Pelajaran Matematika di KecamatanManduamas pada Indikator Tanggapan

\begin{tabular}{|c|c|c|c|}
\hline No & Alternatif Jawaban & Frekuensi & $\mathrm{P}=F / N \times 100 \%$ \\
\hline 1 & Sangat Setuju (SS) & 119 & 56.67 \\
\hline 2 & Setuju (S) & 40 & 19.05 \\
\hline 3 & Ragu-Ragu (RR) & 38 & 18.10 \\
\hline 4 & Tidak Setuju (TS) & 13 & 6.19 \\
\hline & Jumlah & 210 & 100 \\
\hline
\end{tabular}

Berdasarkan tabel di atas dimana hasil angket yang diberikan kepada tiap orang tua siswa kelas VIII-C di SMP Negeri 2 Manduamas terkait dengan persepsi orang tua pada aspek penilaian orang tua pada kegiatan pembelajaran matematika secara daring dari 30 orang tua siswa dengan jumlah pertanyaan 180 pernyataan dimana para orangtua menjawab sangat setuju (SS) sebanyak 119 jawaban atau sekitar $56.67 \%$ dari total jawaban pada indikator penilaian, yang menjawab setuju (S) sebanyak 40 jawaban atau sekitar $19.05 \%$ dari total jawaban pada indikator penilaian. Kemudian jawaban Ragu-Ragu (RR) sebanyak 38 atau sekitar $18.10 \%$ dari total jawaban pada indikator penilaian, selanjutnya jawaban tidak setuju (TS) sebanyak 13 atau $6.19 \%$ dari total jawaban pada indikator penilaian. 


\section{PEMBAHASAN}

Berdasarkan hasil pengumpulan data dan dilakukan perhitungan maka hasil dari analisis perhitungan menunjukkan beberapa temuan adapun hasil temuan dalam penelitian ini akan dibahas sebagai berikut. Sesuai hasil penelitian dari angket yang dibagikan kepada 30 orangtua siswa diketahui bahwa pencapaian skor tertinggi yang diraih adalah 4,00 dan yang terendah adalah 2.35. kemudian setelah dilakukan perhitungan diperoleh nilai mean sebesar 3.16 dan nilai median sebesar 3.38 adapun nilai modus adalah sebesar 3.28. Kemudian adapun hasil penelitian pada tiap indikator diketahui pada indikator perhatian mayoritas orangtua siswa kelas VIII-C menjawab sangat setuju (SS) sebanyak 112 jawaban atau sekitar $53.33 \%$ dari total jawaban. Kemudian nilai rata-rata dari indikator perhatian diperoleh sebesar 3.13 yakni berada pada katagori sangat baik dengan artian persepsi orang tua pada aspek perhatian berada pada kategori sangat baik. Dengan demikian dapat disimpulkan pada indikator perhatian diperoleh kesimpulan mayoritas menjawab sangat setuju dengan artian orang tua menaruh perhatian kepada anak saat belajar secara daring pada pembelajaran matematika sangat perlu. Hal ini sejalan dengan pendapat Laksmi (2017:34) menyatakan bahwa "Keterlibatan orang tua sangat dibutuhkan dalam proses pembelajaran daring, minimal dalam bentuk monitoring dengan cara keterlibatan, fokus, konsisten dan menguat serta memberi solusi kepada anak. Selanjutnya orang tua juga harus serba tahu dan terampil dalam menguasai materi pelajaran dan materi yang dihadapi anak". Kemudian Djamarah (2011:242) menyatakan bahwa, "Perhatian orang tua yang tidak memadai akan membuat anak merasa kecewa dan mungkin frustrasi melihat orang tuanya yang tidak pernah memperhatikannya." Kemudian menurut Nika (2020:153) menyatakan bahwa "orang tua yang selalu memberi perhatian pada anaknya, terutama perhatian pada kegiatan belajar mereka dirumah, akan membuat anak lebih giat dan lebih bersemangat dalam belajar karena ia tahu bahwa bukan dirinya sendiri saja yang berkeinginan untuk maju, akan tetapi orang tuanya juga memiliki keinginan yang sama. Sehingga hasil belajar atau prestasi belajar yang diraih oleh siswa menjadi lebih baik." Selanjutnya Valeza (2017:76) dimana penelitian ini menunjukkan peran orang tua dalam menentukan prestasi belajar siswa sangatlah besar.

Kemudian hasil angket yang diberikan kepada tiap orang tua siswa kelas VIII-C di SMP Negeri 2 Manduamas terkait dengan persepsi orang tua pada aspek tanggapan atau respon orang tua pada anak saat pembelajaran daring pada mata pelajaran matematika dari 30 orang tua siswa dengan jumlah pertanyaan 210 pernyataan dimana para orangtua menjawab sangat setuju (SS) sebanyak 112 jawaban atau sekitar $53.33 \%$ dari total jawaban. Nilai rata-rata dari indikator perhatian diperoleh sebesar 3.20 yakni berada pada katagori sangat baik dengan artian persepsi orang tua pada aspek perhatian berada pada kategori sangat baik. Tanggapan merupakan kesan yang diperlihatkan oleh seseorang setelah mengamati suatu objek. Dengan demikian dari hasil nilai rata-rata pada indikator tanggapan (kesan) orangtua siswa kelas VIII-C memberikan tanggapan sangat baik terhadap proses pembelajaran matematika secara daring. Hal ini sejalan dengan pendapat Suryabrata (2012:36) menyatakan bahwa "Tanggapan selain menghidupkan kembali apa yang telah dipersepsi juga dapat mengantisipasi sesuatu yang akan datang atau yang terjadi saat ini."

Selanjutnya hasil angket yang diberikan kepada tiap orang tua siswa kelas VIII-C di SMP Negeri 2 Manduamas terkait dengan persepsi orang tua pada aspek penilaian orang tua pada kegiatan pembelajaran matematika secara daring dari 30 orang tua siswa dengan jumlah pertanyaan 180 pernyataan dimana para orangtua menjawab sangat setuju (SS) sebanyak 119 jawaban atau sekitar $56.67 \%$ dari total jawaban. Sedangkan nilai rata-rata dari indikator perhatian diperoleh sebesar 3.20 yakni berada pada katagori sangat baik dengan artian persepsi orang tua pada aspek penilaian berada pada kategori sangat baik. Penilaian individu berbeda -beda meskipun objeknya sama berdasarkan hasil angket yang disebarkan dapat disimpulkan bahwa orangtua siswa kelas VIII-C memberikan penilaian yang baik terhadap proses pembelajaran matematika secara daring. Atiqoh (2020:49) yang menjelaskan bahwa menjaga kekompakan dengan anak dapat berpengaruh pada tumbuh kembang anak, anak tumbuh menjadi pribadi yang lebih baik dan dia tidak akan terpengaruh pada hal yang negatif.

Persepsi seseorang dapat dilihat dari beberapa aspek seperti perhatiannya terhadap objek yang dipersepsikan kemudian pendapatnya terhadap objek tersebut. Yamanda (2018:3) menyatakan bahwa, "Persepsi merupakan tanggapan, pemaknaan, penafsiran terhadap stimulus tentang objek yang diamati atau yang dialami yang selalu tertinggal jejaknya dan kesannya di dalam diri kita serta pengaturan informasi indrawi, melalui panca indra". Dengan demikian dapat disimpulkan bahwa persepsi orangtua siswa kelas VIII-C terhadap pelaksanaan pembelajaran daring pada mata pelajaran matematika memiliki persepsi yang baik sehingga para orang tua memperhatikan dan memberikan 
tanggapan serta penilaian yang positif terhadap proses pembelajaran yang dilaksanakan secara daring.

\section{KESIMPULAN}

Berdasarkan analisis data yang dilakukan diperoleh dengan teknik analisis data, maka penelitian ini dapat disimpulkan sebagai berikut sesuai hasil angket yang dibagikan kepada 30 orangtua siswa diketahui bahwa skor tertinggi yang diraih adalah 4,00 dan yang terendah adalah 2.35. kemudian setelah dilakukan perhitungan diperoleh nilai mean sebesar 3.16 dan nilai median sebesar 3.38 adapun nilai modus adalah sebesar 3.28. Gambaran persepsi orangtua siswa kelas VIII$\mathrm{C}$ pada aspek perhatian diperoleh mayoritas menjawab sangat setuju (SS) sebanyak 112 jawaban atau sekitar $53.33 \%$ dari total jawaban dengan nilai rata-rata sebesar 3.13 yakni berada pada katagori sangat baik dengan artian persepsi orang tua pada aspek perhatian berada pada kategori sangat baik. Gambaran persepsi orangtua siswa kelas VIII-C pada aspek tanggapan (respon) diperoleh mayoritas menjawab sangat setuju (SS) sebanyak 112 jawaban atau sekitar 53.33\% dari total jawaban dengan nilai rata-rata dari indikator perhatian diperoleh sebesar 3.20 yakni berada pada katagori sangat baik dengan artian persepsi orang tua pada aspek perhatian berada pada kategori sangat baik. Gambaran persepsi orangtua siswa kelas VIII-C pada aspek tanggapan (respon) diperoleh mayoritas menjawab sangat setuju (SS) sebanyak 119 jawaban atau sekitar $56.67 \%$ dari total jawaban dengan nilai ratarata dari indikator perhatian diperoleh sebesar 3.14 yakni berada pada katagori sangat baik dengan artian persepsi orang tua pada aspek penilaian berada pada kategori sangat baik.

Saran

Berdasarkan kesimpulan dan implikasi hasil penelitian di atas maka adapun yang menjadi saran penulis adalah sebagai berikut siswa, diharapkan mampu meningkatkan cara belajarnya selama pandemic agar tetap meraih prestasi walaupun pembelajaran dilakukan secara daring. Guru, khususnya bidang studi matematika hendaknya dalam menyampaikan materi hendaknya dapat dan mampu meningkatkan keterampilannya sebagai tenaga pendidik yang professional agar tercipta mutu pendidikan yang lebih unggul dan bersaing. Kepada para orangtua agar terus memperhatikan kebutuhan anaknya selama pembelajaran secara daring dan terus mengawasi proses pembelajaran selama dilaksanakan di rumah atau secara daring. Bagi para peneliti di bidang pendidikan khususnya jurusan Pendidikan matematika disarankan untuk mengadakan penelitian yang sejenis yang melibatkan variabel lain yang berkaitan dengan permasalahan dalam pembelajaran.

\section{DAFTAR PUSTAKA}

Abu Ahmadi, 2012. Psikologi Umum, Surabaya: Bina Ilmu.

Laksmi, Dewi. 2017. Rancangan Program Pembelajaran Daring Di Perguruan Tinggi: Studi Kasus Pada Mata Kuliah Kurikulum Pem-Belajar Di Universitas Pendidikan Indonesia. Jurnal Edutech, Vol.16, No.2, Juni 2017.

Atiqoh, Lia Nur Bela Dina. 2020. Respon Orang Tua Terhadap Pembelajaran Daring Pada Masa Pandemi Covid-19. Volume 2 Nomor 1 Tahun 2020.

Nika Cahyati. 2020. Peran Orang Tua Dalam Menerapkan Pembelajaran di Rumah Saat Pandemi Covid 19. Jurnal Golden Age, Universitas Hamzanwadi. Vol. 04 No. 1,

Nurapni, Popy. 2010. Mengenal Tulisan Jurnalistik, Jakarta: Multi KreasiSatudelapan.

Permana, Gerry Krista. 2016. PersepsiSiswa dan Guru TerhadapPelaksanaanPembelajaranBerbasis E-Learning di SMK Negeri 4 Jakarta. JurnalJurusan Teknik SipilFakultas Teknik. Universitas Negeri Jakarta. Mei 2018.

Safitri, Irwina. 2015. Persepsi Orang Tua Murid tentang Pendidikan dan Dukunga Menyekolahkan Anak (Studi Kasus SMP Negeri 1 Jambu Kabupaten Semarang). Jurnal Fakultas Tarbiyah dan Ilmu Keguruan. Vol.1, No. 1, Mei 2015.

Simanjuntak, D. R., Ritonga, M. N., \& Harahap, M. S. (2020). Analisis Kesulitan Belajar Siswa Melaksanakan Pembelajaran Secara Daring Selama Masa Pandemi Covid-19 Oleh.

Mathematic Education Journal)MathEdu, 3(3), 142-146. http://journal.ipts.ac.id/index.php/

Siregar, Nina Siti Salmaniah. 2013. Persepsi Orang Tua terhadap Pentingnya Pendidikan Bagi Anak. Jurnal Ilmu Pemerintahan dan Sosial Politik, Vol.1, No.1, April 2013.

Slameto. 2010. Belajar dan Faktor-faktor yang Mempengaruhi, Jakarta: Rineka Cipta.

Sofyana, Lacjuba. 2019. Pembelajaran Daring KombinasiBerbasisWhatsapp Pada Kelas Karyawan $\begin{array}{lllll}\text { Prodi Teknik InformatikaUniversitas PGRI } & \text { Madiun.JurnalUniversitas } & \text { PGRI }\end{array}$ Madiun Vol.8, No 1.Juni 2019. 
ISSN. 2621-9832

JURNAL MathEdu (Mathematic Education Journal) http://journal.ipts.ac.id/index.php/MathEdu Vol. 4 No. 2 Juli 2021

Steede. Kevin. 2007. 10 Kesalahan Orang Tua dalam Mendidik Anak. Jakarta: Tangga Pustaka.

Sugiyono. 2005. Metode Penelitian Pendidikan pendekatan kuantitatif, kualitatif dan R\&D. Bandung: Alfabeta.

Suryabrata, Sumadi, 2012. Psikologi Pendidikan. Jakarta: Rineka Cipta.

Valeza, Alsi R. 2017. Peran Orang Tua dalam Meningkatkan Prestasi Anak di Perum Tanjung Raya Permai Kelurahan Pematang Wangi Kecamatan Tanjung Senang Bandar Lampung. Skripsi: UIN Raden Intan Lampung.

Yamanda, Mutiara. 2018. Persepsi Orang Tua terhadap Pendidikan Anak Usia Dini di Desa Bantunan Kecamatan Pajar Bulan Kabupaten Lahat. Skripsi Fakultas Keguruan dan Ilmu Pendidikan Universitas Sriwijaya. 